\title{
Measuring the Impact of Urban Air Pollution: Hedonic Price Analysis and Health Production Function
}

\author{
Endah Saptutyningsih, Ahmad Ma'ruf \\ Department of Economics, Muhammadiyah University of Yogyakarta \\ Jalan Lingkar Selatan, Tamantirto, Kasihan Bantul, Yogyakarta, Indonesia 55283 \\ Correspondence e-mail: endahsaptuty@gmail.com, macrov_jogja@yahoo.com
}

Received: June 2015; Accepted: October 2015

\begin{abstract}
This study aims to value air quality from the urban housing market in Yogyakarta City. It is also provides estimation of marginal willingness to pay for the air quality improvement and estimation of the consumer surplus due to reduce of air quality. The methodological framework for estimation is based on a hedonic price model. The result of hedonic price method concludes that by adopting a two-stage estimation procedure to estimate the relationship between air quality and property value, on the average, an increase in the level of $\mathrm{O} 3$ by one percent will increases the property price by 0.063 percent. By using a health production function and demand function mitigation can be seen that the medical history of the individual has effect on the number of working days lost. Meanwhile, O3 pollution has positive effect on the amount of medical expenses for mitigation. Decreasing in O3 pollution causes a decrease in the level of medical expenses to mitigate. Therefore, it is important to reduce the negative impacts of air pollution.
\end{abstract}

Keywords: willingness to pay, hedonic price, consumer surplus, health production function JEL Classification: Q51, Q53, I12, I20

\section{Mengukur Dampak Polusi Udara Perkotaan: Analisis Harga Hedonik dan Fungsi Produksi Kesehatan}

\begin{abstract}
Abstrak
Studi ini bertujuan untuk menilai kualitas udara ditinjau dari pasar properti di Kota Yogyakarta. Studi ini juga mengestimasi marginal willingness to pay perbaikan kualitas udara dan estimasi surplus konsumen karena adanya penurunan kualitas udara. Kerangka metodologis untuk estimasi didasarkan pada model hedonic price. Hasil metode hedonic price menyimpulkan bahwa dengan mengadopsi prosedur estimasi dua tahap untuk mengestimasi hubungan antara kualitas udara dan nilai properti, peningkatan level O3 sebesar satu persen akan menaikkan harga properti sebesar 0,063 persen. Dengan menggunakan fungsi produksi kesehatan dan fungsi permintaan mitigasi dapat dilihat bahwa riwayat kesehatan individu memiliki efek terhadap jumlah hari kerja yang hilang. Polusi O3 memiliki efek positif terhadap jumlah pengeluaran medis untuk mitigasi. Penurunan level polusi O3 menyebabkan penurunan pengeluaran medis untuk mitigasi. Oleh karena itu, sangatlah penting untuk mengurangi dampak negatif polusi udara.
\end{abstract}

Kata kunci: willingness to pay, hedonic price, surplus konsumen, fungsi produksi kesehatan

Klasifikasi JEL: Q51, Q53,I12, I20

\section{Introduction}

The increasing number of land conversion and lack of green open spaces in urban areas is one of the consequences of the increase in economic activities in urban areas. It is characterized by the increasing number of residential, industrial, commercial centers and others. However, circumstances which developed economically but was not offset by the improvement of ecology. Many environmental problems arise from the disruption of the ecological balance eg increasing temperatures, coastal erosion, air 


\section{Jurnal Ekonomi Pembangunan, 16 (2), Desember 2015, 146-157}

pollution, such as the increasing concentration of carbon monoxide (CO), lead (Pb) PM10 and Ozone (Eden et.al., 2005). Sources of air pollution, primarily from the burning of fossil earth is happening in the industry, household and motor vehicles.

Model hedonic price was used to estimate the benefits of reducing air pollution to levels that are safe for local households in the cities of Delhi and Kolkata in India among other health benefits, convenience and environmental benefits of reducing air pollution in urban areas can be estimated by using a model of hedonic price through household survey. The average air pollution SPM, SO2 and NOx concentrations per month indicated by the six monitoring stations in Delhi and 22 monitoring stations in Kolkata. In this study, the hedonic price models will be used to estimate the benefits to local households to reduce O3 pollution to safe levels in the district /city in the province of Yogyakarta Special Region (DIY). Total benefits consisting of health benefits, and environmental benefits of ease of $\mathrm{O} 3$ pollution reduction can be estimated using a model of hedonic price models.

Several studies on health have shown a significant relationship between the concentration of air pollutants with health impacts (Ostro, et al., 1996). Air pollution can lead to various health problems including eye irritation, asthma, bronchitis, etc., that may result in a decrease in work productivity. Given the health effects of air pollution is significant, it is necessary to include explicitly in economic planning. Economic valuation needed to calculate the benefits of improved air quality. Due to the nature of the environment that has the characteristics of public goods, market prices to estimate air pollution reduction benefits are not available. However, by using non-market valuation techniques, benefit reduction in air pollution can be evaluated. Economic valuation of this kind will enable policy makers to compare the benefits of reduced air pollution at a cost reduction of pollution and to provide input in the design of policies to improve air quality and control mechanisms. In addition to using hedonic price models, this study also used the health production function to estimate health benefits for people in areas that have the high- est O3 pollution in Yogyakarta province.

Since the studies conducted by Ridker and Hennings (1967), hedonic price method has been a long debate about several issues. The debate on the identification of functional forms that eventually shifted in favor of simple functional forms (Haab and McConnell, 2003). Segmentation problems of the housing market is still attractive, especially from housing economist. This study aimed to determine the extent of air pollution effect on the value of the property concerned.

Hedonic price method is to estimate the demand for or price of goods that do not have traditional economic market (Lipscomb, 2007). This method is used to examine the constituent characteristics, and estimate the value of each characteristic. In the case of housing, which is a bundle of goods heterogeneous, researchers have made use of hedonic price to assess the implicit prices for various characteristics associated with the property, such as structural components, environmental factors, public services, urban form, and others. In the field of environmental economics, Kim, Phipps and Anselin (2003) developed an econometric model of spatial hedonic housing price to estimate the value of a marginal increase in the concentration of SO2 and NOx for the Seoul metropolitan area. They found that levels of SO2 pollution has a significant impact on the price of housing whilst NOx pollution is not. Hedonic price models are also used to check the capitalization of public services. Edel and Sclar (1974) and King (1977) indicated the need to include the size of the public service and tax is paid in the hedonic price analysis.

Many studies show that (1) hedonic price is a powerful tool in assessing the various components of housing values and (2) certain elements of urban form can be capitalized into property values. However, some of the potential problems associated with hedonic price analysis has not been fully resolved: (1) problems associated with the use of spatial autocorrelation spatial data, and (2) self-selection bias associated with the use of the transaction based on the data in housing prices.

The value of some of the land associated with the flow of benefits derived from the land. 


\section{Jurnal Ekonomi Pembangunan, 16 (2), Desember 2015, 146-157}

Agricultural output and residence are examples of such benefits, but access to the workplace, to commercial amenities, and to environmental facilities such as parks, and the quality of the environment in which the land is located is also an important benefit which is added to the person who has the right to use part of the land, Property value approach to the measurement of the estimated benefits are based on the following assumptions. Considered that different locations have varied environmental attributes, such variation will lead to differences in property values.

Identification of the effects of the price of property (property price effect) due to differences in the level of pollution is usually done by using multiple regression where the data time series, or cross section, or both (pooled data). Commodities can be distinguished based on the characteristics they have and the price is a function of these characteristics. From the standpoint of owners, property land can be distinguished in terms of location, size and quality of the local environment. Considering the price of a product as a function of the characteristics, by differentiating this function according to the characteristic, one can lower the marginal willingness to pay to pay for that characteristic. Environmental characteristics such as air or water quality affect land prices well as a good producer or as a consumer good. Ridker (1967) and Ridker and Henning (1976) provide the first empirical evidence that air pollution affects the value of the property. Freeman (1974), and Rosen in 1974 using hedonic price theory to interpret the derivative of the function hedonic property price related to air pollution as implicit marginal price and the value of a marginal increase in air pollution.

Differences in the value of residential property may arise as a result of a variety of sources such as the number and quality of accommodation available, the accessibility of the business center, the level and quality of public facilities, the level of taxes paid on the property, and the characteristics of the surrounding environment, as measured by the level of air pollution, congestion and noise aircraft, and access to the garden and water facilities. In order to take the effects of these variables on the value of a property, they should all be included in the analysis. Therefore, studies typically involve a variable number of properties, some neighborhood variables, number of variables accessibility, and environment variables. If the relevant variables not included in the analysis, then the effect on the estimated value of the property may be biased. Whether bias up or down will depend on how the variables are included or excluded in touch with each other and related to property values.

This study aims to measure the impact of urban air pollution especially $\mathrm{O}_{3}$ pollutant on willingness to pay of individuals in Jogjakarta City for improving air quality and estimating the factors which determine the work day lost and mitigating activities for reducing the air pollution.

\section{Research Method}

\subsection{Data Types and Sources of Data}

The type of data used are primary data and secondary data, primary data is data obtained directly from the data source.Data for estimating the hedonic property value models obtained through household surveys. For each district / city in the province of Yogyakarta Special Region, will be taken a sample of 150 households representing the households of different environmental monitoring.

The survey asked about the structural characteristics, neighborhood, environmental and socio-economic households. Estimation of hedonic price function is done in two stages. First, estimating the hedonic property value function that reveals the monthly rent each house as a function of structural characteristics, neighborhood and household environment and calculate the implicit marginal house prices for the quality of the environment. Second, the function of the marginal willingness to pay households for the quality of the environment is estimated to express the implicit marginal rent as a function of the quality characteristics of the environmental and socio-economic households.

The second type of data is secondary data, secondary data is the data obtained from agencies and related institutions in the most vulnerable areas $\mathrm{O} 3$ pollution in Yogyakarta that has 


\section{Jurnal Ekonomi Pembangunan, 16 (2), Desember 2015, 146-157}

been identified in the first study year. The agencies include: the National Land Agency (BPN), Directorate General of Taxation, Regional Development Planning Agency (Bappeda), and others. Type of secondary data is required, among others: 1) The number of population of the district/city in the province, 2) Data property prices districts / cities in DIY, 3) Data Object Selling Value Tax, 4) Characteristics of the location of vulnerable areas of air pollution in DIY, 5) Gross Domestic Income districts / cities in DIY.

\subsection{Method of Data Collection}

1. Focus Group. This study will use hedonic price approach that will analyze various factors that influence property prices in the area most vulnerable to air pollution in Yogyakarta province based on research results in the first year). The survey was conducted to explore various characteristics of the building, the physical and social environment in the region. Mitchell and Carson (1989) recommends the use of focus groups and pre-test in order to structure the best WTP question. The main purpose of focus group is revealing the best way to ask a very technical question related to property and land prices.

2. Pre-test. Pre-test was used to estimate the time required to survey, identify issues further or clarification needed for the questions in the questionnaire and make the final format of questions that will be used. Slight modifications were made on questions related to hedonic price following the change that is supported by focus group.

3. Final Survey. The survey was conducted in the area most vulnerable to air pollution by the respondent. In addition to questions related to price and characteristics of the property, the survey also included questions about physical and social environment, as well as community awareness on the environment.

\subsection{Sampling Technique}

Book study method used to collect secondary data relevant to the calculation of losses due to ozone pollution in the area most vulnerable to air pollution are already identified in the first year. While primary data obtained by sampled beforehand by using the strategic random sample (Scheaffer et. al., 1996), meaning that all the houses are located in the most vulnerable areas Ozone pollution is divided into several blocks, and then the samples were randomly assigned to each block. Samples used because not all units in the population can be identified, the cost and time spent fewer than counting the population. The sample size used by the formula Watson et al. (1993) are:

$$
n=\frac{4 Z_{1 / 2 \alpha}^{2} p(1-p)}{(\omega)^{2}}
$$

Where $\mathrm{n}=$ sample size; $\mathrm{p}=$ proportion of the expected success of the sample; $q=$ proportion of residual (1-p); Z1 / 2 $\alpha=$ coefficient of confidence; $\omega=$ the number of errors that can be tolerated from the average population at the left boundary $(\mathrm{L})$ and right limits $(\mathrm{R})$, so that $\omega=\mathrm{L}+\mathrm{R}$.

\subsection{Operational Definitions}

1. The economic valuation is giving value (value) is economically on an event or the impact on natural resources and the environment, in which the human being as subject and object of the activity that caused these effects (Titienberg, 1998),

2. Property prices can be interpreted as a Tax Object Selling Value (NJOP) home from the Government. In general, the value of selling houses in the property market is higher than NJOP,

3. Variable property describes the characteristics of the property include the number of rooms, number of bathrooms, the age of the building, the size of the land, the size of the building, the type of building (permanent, semipermanent, not both),

4. Variable neighborhood for objects such as property include a distance to the shopping center, the distance from the road, distance from a seedy neighborhood, the distance from the central office and industrial, building density (Brookshire, Thayer, Schulze and d'Arge, 1982), and income level,

5. The environment variable indicates the risk characteristics of air pollution include the perception of air quality, ozone content; the density 


\section{Jurnal Ekonomi Pembangunan, 16 (2), Desember 2015, 146-157}

of motor vehicles (already obtained the data in the first year) and the dummy availability of trees,

6. Marginal willingness to pay is a willingness to pay extra each unit change in the concentration of ozone or implicit marginal price (marginal implicit price) environmental quality.

\subsection{Analysis Tools}

\section{Hedonic Property Price}

Ridker (1967) and Ridker and Henning (1976) provide the first empirical evidence that air pollution affects the value of the property. Freeman (1974), and Rosen in 1974 using hedonic price theory to interpret the derivative of the function hedonic property price related to air pollution as implicit marginal price and the value of a marginal increase in air pollution. Property value approach to the measurement of the estimated benefits are based on the following assumptions. Considered that different locations have varied environmental attributes, such variation will lead to differences in property values. The first stage of the hedonic property value approach is to estimate the following equation: Property value $=\mathrm{f}$ (property variables, neighborhood variables, environmental variables) or

\section{$\mathrm{PP}=\mathrm{f}(\mathrm{PROP}, \mathrm{NHOOD}, \mathrm{ENV})$}

The actual specification of this equation is a problem in the choice of professionals. One of the familiar are:

$\ln \mathrm{PP}=\mathrm{a} \ln \mathrm{PROP}+\mathrm{b} \ln \mathrm{NHOOD}+\mathrm{c} \ln \mathrm{NV}$

where PP is the price of the property, PROP is property characteristics, HOOD is the characteristics associated with the location of the property, ENV is a variable risk of air pollution associated with property prices.

\subsection{The Health Production Function}

The study used the health production function for estimating the economic benefits of a reduction in morbidity due to a decrease in air pollution in the city of Yogyakarta. Health production function and the function of the demand for mitigation activities are implicit in the behavior of individual utility maximization refer to Freeman (1993). Empirically, this study estimates two reduced-form equation that consists of health production function and demand mitigation activities to estimate the marginal effect of pollution on $\mathrm{H}$ and $\mathrm{M}$. The equations of each are:

$$
\begin{aligned}
H= & \alpha_{i}+\beta_{1} O_{3}+\beta_{2} \text { age }+\beta_{3} \text { age } e^{2}+\beta_{4} \text { educ }+\beta_{5} \\
& \text { inc }+\beta_{6} \text { gender }+\beta_{7} \text { illness }+v \\
M= & \gamma_{1}+\delta_{1} O_{3}+\delta_{2} \text { age }+\delta_{3} \text { age } e^{2}+\beta_{4} \text { educ }+\delta_{5} \\
& \text { inc }+\delta_{6} \text { gender }+\delta_{7} \text { illness }+\varpi
\end{aligned}
$$

The dependent variable in the equation above is: Work days lost $(\mathrm{H})$ show the number of working days lost per person per week because of diseases caused by air pollution; Mitigation activities (M) is a disease-related expenditures as a result of air pollution. These expenses include medical costs, physician fees, diagnostic tests, hospital fees, travel costs to the clinic, and so on. per person per month. The independent variables that affect the health production function and mitigation activities: Pollution Ozone (O3) shows O3 concentration in the air in ppm; Age (Age) is the age of the individual. With increasing age, health capacity will declined and therefore susceptible to illness and increased mitigation activities; Education (educ) shows the education level of individuals who have attained; Income (inc) shows the amount of individual income per month; Sex (gender) is a dummy variable 1 if male and 0 if female; Disease (illness) such as asthma, cough, fever indicated by a dummy variable 1 if the individual is suffering from a particular disease, and 0 if not.

\section{Results and Discussion}

\section{Hedonic Price Estimation}

In order to estimate the hedonic price function, it is necessary to collect data on all the characteristics that are relevant to the selling price of the home. The variables described, the price of the house, is a function of environmental variables, structural and neighborhood. 
Avalaible online at http://journals.ums.ac.id

Jurnal Ekonomi Pembangunan, 16 (2), Desember 2015, 146-157

Table 1. Statistic Descriptive

\begin{tabular}{llrc}
\hline \multicolumn{1}{c}{ Variables } & \multicolumn{1}{c}{ Description } & Mean & St.Dev \\
\hline PPRICE & Selling price of property (Rupiah) & $3 \mathrm{E}+08$ & 243617628,2 \\
LANDSIZE & Land area $\left(\mathrm{m}^{2}\right)$ & 206,05 & 198,288 \\
BUILDSIZE & Building area $\left(\mathrm{m}^{2}\right)$ & 124,28 & 111,246 \\
NUMROOM & Number of rooms (unit) & 4,00 & 4,614 \\
WSTRUCT & Dummy wall structure & 1,15 & 0,497 \\
DISSCHOOL & Distance to school (m) & 512,94 & 555,328 \\
DISHPITAL & Distance to hospital (m) & 956,26 & 802,810 \\
DISPMARKET & Distance to supermarket (m) & 990,68 & 867,411 \\
DISREST & Distance to restaurant (m) & 642,64 & 785,568 \\
DISCITY & Distance to central city (m) & 2062,0 & 1592,980 \\
DISMSTREET & Distance to main road (m) & 192,01 & 165,511 \\
GARDENDU & Dummy proximity to the park & 1,79 & 0,407 \\
INCOMEDUM & Dummy income & 1,88 & 0,509 \\
FAMEMBER & Number of family members (orang) & 3,92 & 1,356 \\
O3 & O3 concentration (ppm) & 0.0032 & 0.001 \\
\hline
\end{tabular}

These data related to the residential area in Jogjakarta City. A total of 250 heads of households were interviewed using a structured questionnaire. Table 1 indicates that the average house price of 300 million rupiah. The area of land is one of the important variables that affect the price of the house. The average land area is 206.5 square meters. While the average building area is 124.28 square meters. Other factors that affect the price of the house is owned by a number of rooms. The average number of rooms owned is four bedroom units. Among the variables neighborhood, six of them covering a distance of schools, hospitals, supermarkets, restaurants, the city, and the main street - are also considered in this study. The distance calculated is the closest distance from homes to the location. The average distance from school to home is 512.94 meters. Distance from the nearest hospital an average of 956.26 meters. The average distance from the main road is 192 meters. One of the socio-economic variable is the number of family members. On average respondents have family members as much as 4 people.

In the hedonic price models used in this study, concentrations of $\mathrm{O} 3$ used as a measure of air quality. The data used came from the results of monitoring the Environment Agency of Yogyakarta Special Region. O3 concentration on average $0.0032 \mathrm{ppm}$.

1) Estimation Model Research. In the estimation of hedonic price equation, it is assumed there is a negative relationship between environmental characteristics $\mathrm{O} 3$ with house prices, while the existence of the park near the house is assumed to have a positive influence. All structural parameters were included in the research model, such as land and buildings, are expected positively related to home prices. Neighborhood characteristics such as distance from the hospital and the restaurant is inversely related to the price of the house. When the distance from the hospital farther away, house prices fell. While the distance from the main road farther, the price of houses is increasing. By applying these assumptions in the model study, the parameters estimated using ordinary least squares method and the results are shown in Table 2.

Table 2. Regression of Hedonic Price function

\begin{tabular}{lc}
\hline Variable & Coefficient \\
\hline (Constant) & $15.879^{* * * *}$ \\
& $(0.630)$ \\
LnLANDSIZE & $0.788^{* * *}$ \\
& $(0.058)$ \\
LnBUILDSIZE & $0.217^{* * *}$ \\
& $(0.074)$ \\
LnDISCITY & $-0.181^{* * *}$ \\
& $(0.047)$ \\
LnDISMSTREET & $0.058^{* *}$ \\
GARDENDUM & $(0.028)$ \\
LnO3 & - \\
& $-0.063^{* *}$ \\
No. Observation & $(0.025)$ \\
Adjusted R ${ }^{2}$ & 250 \\
\hline
\end{tabular}




\section{Jurnal Ekonomi Pembangunan, 16 (2), Desember 2015, 146-157}

The main results of this analysis are as follows: 1) All structural characteristics and neighborhood unless the wall structure, number of rooms, distance from school, and distance from the city statistically significant at the 95 percent confidence level; 2) environmental characteristics, O3, negatively associated with housing prices and significant at the 99 percent confidence level. The results also show that when the 03 concentration increased by 1 percent, the average house price fell by 0.32 percent; 3) Among the characteristics of the neighborhood, where the garden near the house positively related to home prices; 4) The distance from the hospital or restaurant associated negatively with property prices. This shows that the location of the house closer to the hospital or restaurant, the higher house price; 5) The distance from the supermarket or the main street positively associated with property price. This indicates that the greater the distance home from the supermarket or the main street, the higher property prices; 6) The land and buildings are also positively associated with property prices. The regression results of the hedonic price function showed that all the significant variables follow the expected pattern of relationships. Therefore, the estimation equation can be written as follows:

ln PPRICE_O3 $=15.879+0.788$ lnLANDSIZE

$$
\begin{aligned}
& +0.217 \ln \text { BUILDSIZE - } 0.181 \ln \text { DISCITY } \\
& -0.058 \ln \text { DISMSTREET - } 0.063 \ln \mathrm{O} 3+\mathrm{e}
\end{aligned}
$$

2) Calculation of Marginal Implicit Price. The first derivative of the hedonic price function can be interpreted as a function of the marginal implicit price for environmental goods. Descriptive statistics implicit marginal prices for 250 observations are shown in Table 3,

3) Implicit Demand Function. As has been described above that the estimate of the second phase of the inverse demand curve is done by performing regression implicit marginal price (marginal implicit price) to the quantity of environmental goods purchased and socioeconomic factors, including the level of income of another individual. The regression results are shown in Table 4.

Table 3. Descriptive statistics of Implicit Marginal Price

\begin{tabular}{lc}
\hline Descriptive Statistics & $\begin{array}{c}\text { Implicit Marginal } \\
\text { Price (Rupiahs) }\end{array}$ \\
\hline Mean & $9 \mathrm{E}+006$ \\
Standard error & $8 \mathrm{E}+005$ \\
Median & $5 \mathrm{E}+006$ \\
Mode & $2 \mathrm{E}+006$ \\
Standar deviation & $1 \mathrm{E}+007$ \\
Minimum & $2 \mathrm{E}+005$ \\
Maximum & $1 \mathrm{E}+08$ \\
\hline
\end{tabular}

Table 4. Estimates Inverse Demand Function $\mathrm{O}_{3}$

\begin{tabular}{lc}
\hline Variable & Coefficient \\
\hline (Constant) & $13.010^{* * * *}$ \\
INCOMELEVEL & $(0.606)$ \\
LnLANDSIZE & - \\
& $0.781^{* * *}$ \\
LnBUILDSIZE & $(0.058)$ \\
WALLSTRUCTDUM & $0.220^{* * *}$ \\
LnNUMROOM & $(0.074)$ \\
LnDISSCHOOL & - \\
LnDISHOSPITAL & - \\
LnDISSUPERMARKET & - \\
LnDISRESTAURANT & - \\
LnDISCITY & - \\
& - \\
LnDISMAINSTREET & $-0.176^{* * *}$ \\
GARDENDUM & $(0.047)$ \\
Ln O3 & $-0.058^{* *}$ \\
\hline No. Observation & $(0.028)$ \\
Adjusted R & - \\
\hline
\end{tabular}

Regression results concluded that: 1) The first derivative of the function of the marginal implicit price for $\mathrm{O} 3$ is negative $(-1071)$ shows that an increase in prices by the implicit marginal environmental degradation. This means that the research sites, a decrease of 1 percent 


\section{Jurnal Ekonomi Pembangunan, 16 (2), Desember 2015, 146-157}

O3 concentration leads to an increase in home values of 1.071 percent; 2) coefficient variable income levels, the structure of the walls of the house, number of rooms, distance from school, and the distance from hospitals, supermarkets, and restaurants, as well as the proximity to the park is not significant; 3) All other variables except the number of family members, the structure of the wall, the distance from the school, and distance from the city significantly on the degree of confidence of 95 percent. It is interesting to note that the increase in distance from the main road by 1 percent, resulting in home value increased by 0.058 percent; 4) The land and building positive effect on the value of the home. The regression results above show that households are willing to pay for air quality improvements.

4) Estimates of Consumer Surplus. Variations in consumer surplus due to a decrease in air quality is calculated by using the definite integral of the inverse demand function with the level of quality limits the beginning and end. O3 pollution level is assumed to fall by 10 percent. Pollutant $\mathrm{O} 3$ coefficient can be used to lower the consumer surplus for a change of pollutants and estimated as follows :

$$
\begin{gathered}
C S_{O 3}=e^{13.01} . \text { landsize }^{0.781} \cdot \text { buildsize }^{0.22} \cdot \text { discity }^{-0.176} \\
\text { dismainstreet }^{-0.058} \cdot \frac{1}{-1.071+1}\left[\text { lowerlim }^{-1.071+1}\right) \\
\left.-\left(03^{-1.071+1}\right)\right]
\end{gathered}
$$

Based on the calculation above, the average consumer surplus per person if there is a decrease of 10 percent $\mathrm{O} 3$ pollution is as much as 30 million.

Table 5. Consumer Surplus

\begin{tabular}{rr}
\hline Mean & $30,000,000$ \\
Standard Error & $2,000,000$ \\
Median & $20,000,000$ \\
Mode & $20,000,000$ \\
Standard Deviation & $40,000,000$ \\
Minimum & $30,000,000$ \\
Maximum & $50,000,000$ \\
\hline
\end{tabular}

\section{Health Production Function Estimation Results}

Estimation of health production function and demand function mitigation activities using Tobit regression model are shown in Table 6 and 7. Health production function to estimate the working days lost. Table 6 and 7 each showing a reduced-form equation parameters estimated working days lost and expenditure on mitigation described in the function of the physical and socio-economic variables.

Health production function or equation for working days lost is estimated as a reduced form as shown in column (2) in Table 6, O3 pollution parameter coefficient is positive indicates that the increasing number of working days lost due to increased pollution levels. O3 pollution variables affect significantly the level of 10 percent.

\begin{tabular}{|c|c|}
\hline Independent Variables & Coefficient \\
\hline $\mathrm{O}_{3}$ & $\begin{array}{c}0.0037^{*} \\
(222.796)\end{array}$ \\
\hline AGE & $\begin{array}{l}-0.0213 \\
(0.1052)\end{array}$ \\
\hline AGE_SQ & $\begin{array}{c}0.0001 \\
(0.0010)\end{array}$ \\
\hline YEARS_EDUC & $\begin{array}{l}-0.0118 \\
(0.0796)\end{array}$ \\
\hline INC & $\begin{array}{c}7.89 \mathrm{E}-08 \\
(1.34 \mathrm{E}-07)\end{array}$ \\
\hline GENDER & $\begin{array}{c}-0.9361^{* *} \\
(0.4313)\end{array}$ \\
\hline ASTHMA & $\begin{array}{c}12.4241^{* * *} \\
(1.3912)\end{array}$ \\
\hline BATUK & $\begin{array}{c}9.2919^{* * *} \\
(0.8896)\end{array}$ \\
\hline DEMAM & $\begin{array}{c}9.3335^{* * *} \\
(0.9129)\end{array}$ \\
\hline PENY_LAIN & $\begin{array}{c}2.9475^{* * *} \\
(1.1193)\end{array}$ \\
\hline Konstanta & $\begin{array}{c}3.0264 \\
(2.9475) \\
\end{array}$ \\
\hline Log likelihood & -222.486 \\
\hline Adj. R_squared & 0,7165 \\
\hline Uncensored Obs. & 99 \\
\hline Left censored Obs. & 151 \\
\hline
\end{tabular}

Tabel 6. Regression of health production function (work day loss) 


\section{Jurnal Ekonomi Pembangunan, 16 (2), Desember 2015, 146-157}

Socio-economic variables such as age, length of education, income and gender did not affect the number of working days lost. Men have lost working days fewer than women. This is demonstrated by the gender variable coefficient is negative. While the medical history of individuals who have experienced asthma, cough, fever, and other diseases and significant positive effect on the level of one percent.

Tabel 7. Regression of demand function mitigating activities (medical expenditure)

\begin{tabular}{lc}
\hline Variabel Independen & Koefisien \\
\hline $\mathrm{O}_{3}$ & $3.51 \mathrm{E}+05^{* * * *}$ \\
AGE & $(1.42 \mathrm{E}+05)$ \\
& 11577.42 \\
AGE_SQ & $(15896.52)$ \\
& -112.8729 \\
YEARS_EDUC & $(158.8631)$ \\
& $24025.90^{* * *}$ \\
INC & $(12416.69)$ \\
& 0.017393 \\
GENDER & $(0.01994)$ \\
& -47912.40 \\
ASTHMA & $(64916.16)$ \\
& $7570522^{* * *}$ \\
BATUK & $(915390.9)$ \\
& $2285119^{* * * *}$ \\
DEMAM & $(623951.3)$ \\
& $2348619^{* * *}$ \\
PENY_LAIN & $(639190.5)$ \\
& $1736222^{* * * *}$ \\
ASTHMA * $\mathrm{O}_{3}$ & $(183854)$. \\
& $-1.63 \mathrm{E}+06^{* * * *}$ \\
BATUK * $\mathrm{O}_{3}$ & $(2.39 \mathrm{E}+05)$ \\
& $-3.50 \mathrm{E}+05^{* * * *}$ \\
DEMAM * $\mathrm{O}_{3}$ & $(1.50 \mathrm{E}+05)$ \\
& $-3.53 \mathrm{E}+08^{* *}$ \\
Constant & $(1.53 \mathrm{E}+05)$ \\
& -2737946 \\
Log likelihood & $(701220.4)$ \\
Adj. R_squared & -1358.713 \\
Uncensored Obs. & 0.6140 \\
Left censored Obs. & 96 \\
& 154 \\
\hline
\end{tabular}

Dependent Variable: medical expenditure (M). ( ) shows standard error. *significant at level $10 \%$; ${ }^{* *}$ significant at $5 \% ; * * *$ significant at level $1 \%$.

Table 7. shows estimates of the parameters in the equation reduced form of mitigation activities (medical expenses). Pollutant O3 coef- ficient is positive indicates that the reduced expenditures due to lower pollution mitigation O3. O3 pollution is a significant variable effect on mitigation expenditure at the level of one percent. Effects of age indicated by the variable AGE and AGE_SQ. AGE coefficient is positive whereas negative coefficients marked AGE_SQ. However, both of these variables did not significantly affect the mitigation expenses. Long education positively affects medical expenses (mitigation) at the level of five percent. All diseases such as asthma, cough, fever, and other diseases each affect the medical expenditure at the level of one percent. This means that people with the condition of the disease have higher medical expenses. The adverse effects of $\mathrm{O} 3$ pollution against these diseases can be captured in this estimate by the interaction between $\mathrm{O} 3$ pollution with each of these diseases. Results show that the interaction of disease asthma, cough, and fever statistical effect.

\section{Conclusions}

The main objective of this study was to confirm the existence of ties between air quality and value of the property in Yogyakarta province. By mapping the areas that have the highest concentrations of $\mathrm{O} 3$, it is then estimated hedonic value of property in the region, so that it can be shown a link between air quality and property values.

In the model specification, included a variety of variables such as the structure of the home, neighborhood characteristics, environmental and socioeconomic factors as determinants of consumer willingness to pay for improvement of air quality. Researchers hypothesized that environmental variables, $\mathrm{O} 3$ is negatively related to the value of the property. While the size of land and buildings, and the distance from the main road is positively related to the value of the property. Meanwhile, the distance from the town center is negatively related to the value of the property. By applying a two-stage estimation procedure to estimate the relationship, it can be concluded that, on average, increased concentrations of $\mathrm{O} 3$ reduce the price of homes in the study site at 


\section{Jurnal Ekonomi Pembangunan, 16 (2), Desember 2015, 146-157}

0.063 percent. While the average increase in the concentration of $\mathrm{CO}$ reduces the price of homes in the study site by 1,071 percent.

Results of the study estimate that the implicit marginal price for reducing the concentration of $\mathrm{O} 3 \mathrm{Rp} 9$ million. Estimates further show that households are willing to pay an additional amount of 1.07 percent for a reduction in the concentration of $\mathrm{O} 3$. Thus, it can be concluded that there is a positive relationship between air quality and the price of property in Yogyakarta (especially in areas with the highest concentrations of $\mathrm{O} 3$ ).

By using a health production function and the demand function of mitigating it is known that an individual's health history affect the number of working days lost. Meanwhile, O3 pollution positive effect on the amount of medical expenses for mitigation. O3 pollution causes a decrease in the level of medical expenses to mitigate decreased. Various diseases asthma, cough, and fever caused by pollution also affects the amount of medical expenditure for mitigation. Therefore, the need for efforts to reduce the negative impacts of air pollution.

Local governments can use economic valuation as a reference in implementing development policies related to the environment. Government and private sector support is needed to improve the quality of the environment. The next study is expected to be able to calculate the consumer surplus based on research results that have been obtained. This research is also expected to encourage other researchers to conduct similar studies in other urban areas that experienced the problem of air pollution.

\section{References}

Alberini, A. and Krupnick, A. 2000. Cost-of-Illness and Willingness-to-Pay Estimates of the Benefits of Improved Air Quality: Evidence from Taiwan. Land Economics, Vol. 76, No. 1 (Feb., 2000), pp. 37-53.

Badan Pusat Statistik. 2014. Kota Yogyakarta dalam Angka 2014.

Barton, D.N. 1994. Economic factors and valuation of tropical coastal resources. SMRReport 14/94, Bergen, Norway, 128 p.
Brookshire, D. Thayer, Schulze, and d'Arge, Valuing Public Goods: A Comparison of Survey and Hedonic Approaches. AER. March 1982.

Cesar, et.al. 2002. Improving Air Quality in Metropolitan Mexico City an economic valuation. Working Paper Series No. 2785. The World Bank. Washington DC.

Chestnut, L. G., B. D. Ostro, N. Vichit-Vadakan, and K. R. Smith. 1998. Health effects of particulate matter air pollution in Bangkok. Final report. Boulder, Col.: World Bank and the Royal Thai Government.

Cowell PJ and Zeng TQ, 2003. Integrating Uncertainty Theories with GIS for Modeling Coastal Hazards of Climate Change. $M a$ rine Geodesy, 26, 5-18.

Cropper, M., N. Simon,A . Alberini,S . Arora,a nd P. K. Sharma. 1997. The Health benefits of air pollution control in Delhi. American Journal of Agricultural Economics 79 (5): 1625-29.

Cropper, Maureen L. 1981. Measuring the benefits from reduced morbidity, American Economic Review, (71): 235-240.

Davis, L.S., and K.N. Johnson. 1987. Forest Management. $3^{\text {rd }}$ edition. McGraw-Hill Book Cp., New York.

Dixon, John.A. 1996. The Economic valuation of health impacts. Working Paper. The World Bank. Washington DC.

Edel, Matthew and Elliot Sclar. 1974. Taxes, Spending and Property Values: Supply Adjustment in a Tiebout-OOates Model, Journal of Political Economy 82: 941-954.

Edel, Matthew and Elliot Sclar. 1974. Taxes, Spending and Property Values: Supply Adjustment in a Tiebout-OOates Model, Journal of Political Economy 82: 941-954.

Eden, Sally, Sylvia M. Tunstall, and Susan M Tapsell. 2005. Environmental restoration: environmental management or environmental threeat? Area Journal, Volume 31, Issue 2, pp 151-159, Wiley Online Library.

El-Fadel, M. and M Masood (2000), Particulate matter in urban areas: health-based economic assessment. The Science of the Total Environment, (257): 133-146. 


\section{Jurnal Ekonomi Pembangunan, 16 (2), Desember 2015, 146-157}

Evi Gravitiani. 2003. Valuasi Ekonomi Dampak Gas Buang Kendaraan Bermotor terhadap Kesehatan Masyarakat di Kota Yogyakar$t a$. Tesis S2 UGM. Yogyakarta.

Fauzi, A. 2005. Kebijakan Perikanan dan Kelautan. Gramedia Pustaka Utama. 2005. Jakarta.

Firdaus, R. 2013. Benefits of Green Space for air quality improvement and GHG emissions reduction in Jakarta. Thesis. MSc Programme in Urban Management and Development. Rotterdam, Netherland.

Freeman A.M. 1974. Air Pollution and Property Values: a further comment. Review of Economics and Statistics (56) pp: 554-556.

Freeman Ill, M. 1979. Hedonic prices, property values and measuring environmental benefits, a survey of the issues. Scandinavian Journal of Economics, (81), pp: 155173.

Freeman, A. Myrick III, 1993, The Measurement of Environmental and Resource Values: Theory and Methods, Washington, D.C: Resources for the Future, Inc.

Garrod, Guy and Willis, Kenneth.G. 1999. Economic Valuation of The Environment. Edward Elgar. UK.

Gerking, S., and L. Stanley. 1988. An Economic analysis of air pollution and health: The Case of St. Louis. The Review of Economics and Statistics 68 (1): 115-21.

Grossman, M. (1972). On The Concept of Health Capital and Demand for Health. Journal of Political Economic, 80: 223-255.

Gualtieri, G., Tartaglia, M., 1998. Predicting urban traffic air pollution: a GIS framework. Transportation Research Part D: Transport and Environment 3 (5), 329336.

Haab, T. C. and K. E. McConnell (2002), Valuing Environmental and Natural Resources. Cheltenham, UK: Edward Elgar Publishing, 2002.

Haab, Timothy C. and McConnel, Kenneth E. 2003. Valuing Environmental and Natural Resources: the econometrics of non-market valuation. Edward Elgar.
Harmaini, 1998. Penilaian Ekonomi Dampak Gas Buang Kendaraan Bermotor: Studi Kasus DKI Jaya. Tesis Pasca Sarjana UGM. Yogyakarta.

Imam, Moh. Nurul. 2002. Estimasi Biaya Polusi Udara bagi Pengendara Motor di Yogyakarta dengan Contingent Valuation Method. Tesis Pasca Sarjana UGM. Yogyakarta.

Kim, C., T. Phipps, and L. Anselin (2003). Measuring the benefits of air quality improvement: A spatial hedonic approach. Journal of Environmental Economics and Management 45, 24-39.

King, A. Thomas. 1977. Estimating Property Tax Capitalization: A Critical Comment. Journal of Political Economy 85, 2: 425431.

Kumar, S and D N Rao (2001). Valuing Benefits of Air Pollution Abatement Using Health Production Function: A Case study of $\mathrm{Pa}$ nipat Thermal Power Station, India. Journal of Environmental \& Resource Economics, (20): 91-102

Lipscomb, Clifford A. 2007. An Alternative Spatial Hedonic Estimation Approach, Journal of Housing Research 15, 2: 143-160.

Lvovsky, Kseniya. 1998. Economic Costs of Air Pollution With Special Reference to India. Prepared for the National Conference on Health and Environment Delhi, India.

Maddison, D., Pearce, D., Johansson, O., Calthrop, E., Litman, T., Verhoef, E., 1996. The True Costs of Road Transport. London: Earthscan Publications Limited.

Mitchell, R.C. and Carson, R.T., 1989. Using Surveys to Value Public Goods: The Contingent Valuation Method. Resources for the future, Washington DC.

Moaz, Alsherfawi Aljazaerli. 2005. Hedonic Valuation of Marginal Willingness to Pay for Air Quality in Metropolitan Damascus. Forum of International Development Studies, 3 September 2005.

Murty, M. N., S. C. Gulati and A. Banerjee (2003). Health Benefits from Urban-Air Pollution Abatement in the Indian Sub- 


\section{Jurnal Ekonomi Pembangunan, 16 (2), Desember 2015, 146-157}

continent. Discussion Paper no. 62/2003, Institute of Economic Growth Delhi.

Ostro, Bart, D. 1994. The Health Effect of Pollution: A Methodology With Application to Jakarta. Working Paper Series No. 1301. The World Bank. Washington DC.

Ostro, Bart, D., Eskeland, G.S., Aranda, C., and Sanchez, J.M., 1996. Air Pollution and Mortality: Result From A Study os Santiago, Chile. Working Paper Series No. 1453. The World Bank. Washington DC.

Palmquist, R.B., Roka, F., Vukina, T., 1997. Hog operations, environmental effects, and residential property values. Land Econ. 73 (1), 114-124.

Reksohadiprojo, Sukanto, dan Budi Purnomo. 1997. Ekonomi Lingkungan. BPFE. Yogyakarta.

Ridker, Ronald G. 1967. Economic Costs of Air Pollution Studies in Measurement. New York

Ridker, Ronald G. and Henning, John A., 1967. The determinants of residential property values with special reference to air pollution. The Review of Economics and Statistics 49: 246-257

Ridker, Ronald G. and John A. Henning (1976) The Determinants of Residential Property Values with Special Reference to Air Pollution. Review of Economics and Statistics. 49, 246-57.

Rosen, S. 1974. Hedonic Prices and Implicit Markets: Product Differentiation in Perfect Competition. Journal of Political Economy. 82, 34-55
Saptutyningsih, E. 2011. Hedonic Price Price Approach of Flood Effect on Agricultural Land. Economic Journal of Emerging Markets Vol.3 Issue 1, April 2011, p:87-96

Scheaffer, R.L., W. Mendenhall III and R.L. Ott 1996, Elementary Survey Sampling, (5th edition), Duxbury Press, USA.

Smith, V.K., W.H. Desvousges and M.P. McGiveny, 1983, The opportunity cost of travel time in recreation demand models', Land Economics 59: 259-278.

Strauss, J., and Thomas, D. (2008). Health Over The Life Course, Handbook of Development Economics Volume 4: 3376-3465.

Tietenberg, Tom. 1998. Environmental Economics and Policy. $2^{\text {nd }}$ edition. Addison Wesley. USA.

Todaro, Michael P., 2000. Economic Development in The Third World. $7^{\text {th }}$ edition. London. Addison Wesley. Longman Limited.

US. Environment Protection Agency Office of Air and Radiation. 2000. Seri Makalah Hijau, Mutu Udara Kota. Penerjemah IKIP Malang. Washington DC.

Von Neumann, John and Oscar Morgenstern, Theory of Games and Economic Behavior, Princeton, NJ: Princeton University Press, 1944.

Watson, M. 1993. Measures of Fit for Calibrated Models. Journal of Political Economy, 101:1011-1041.

World Bank . 2001. The Quality of Growth. New York.

World Bank. 1992. World Development Report 1992. Oxford University Press. 